\title{
Professor Mels van der Ploeg (1926-2011)
}

My colleagues and I (J.K.) were deeply affected by the news that Mels van der Ploeg passed away on 5 April 2011. In my mind, I returned to several occasions when we had met or exchanged letters over many years. His death is an untold loss for the Dutch and international scientific circle including the Polish histochemical community. He was generally ac-

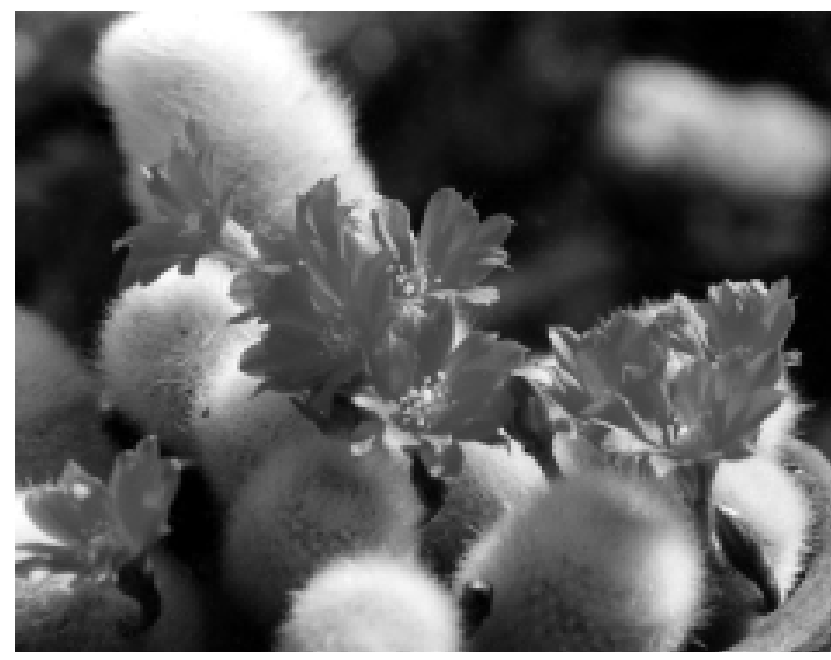
knowledged as a scientist and researcher of international importance, contributing much to progress in cytochemistry and molecular biology.

Mels van der Ploeg was born in Rotterdam on 16September 1926 but spent his adolescence in the former Dutch East India, in Indonesia. He obtained his final secondary school qualifications during the Second World War as an internee in a Japanese P.O.W. camp in Bandung. After the war, he went to study Organic Chemistry at the Free University in Amsterdam, and became Bachelor of Science in 1951, Master of Science in 1956, and obtained his Organic Chemistry Ph.D. in 1963 on the subject of cytochemistry. His thesis was on 'The mechanism of the Peroxidase-DOPA reaction'. Between 1948 and 1964 he was a teacher of chemistry and physics at secondary schools in Rotterdam and Amsterdam. From 1962 to 1974, Mels was Senior Scientist and Assistant Professor in the Department of Histochemistry and Cytochemistry, Faculty of Medicine at Leiden University, and from 1975-1991 Professor of Cytochemistry and Cytometry at the Department. In the laboratory, Mels joined the group of Piet van Duijn, with whom he initiated studies into quantitative enzyme histo- and cytochemistry. In 1978 he was Guest-Professor in the Department of Pathology, University of Perth, Western Australia.

In a note submitted to the Polish Academy of Science and Art (1999), Mels characterized his main research topics as follows: the development and applica- tion of cytochemical procedures for the identification, localization and quantitation of specific nucleic acid sequences in microscopic preparations of cell nuclei and metaphase chromosomes in relation to fundamental medical-biological research, and potential application in cytogenetic, oncological and viral diagnosis. In terms of the progress of biomedical sciences, the most important achievement of his research was the development of the fluorescence in situ hybridization technique.

Mels organized a scientific co-operative group preparing Ph.D. theses, in most cases together with co- and other promoters. This group included: F.Th. Bosman (1976), A.W.C.A. Cornelissen (1982), A.C. van Prooijen-Knegt (1983), B.J. Trask (1985), J.E. Landegent (1987), Ch.J. Janse (1987), N.M. Jiwa (1989), H.van Dekken (1989), R.F. Kooy (1991), R.H. Boerman (1991), E.P.J. Arnoldus, R.W. Dirks (1992), J. Vrolijk (1993), and J. Wiegant (1994).

The scientific output of Mels van der Ploeg includes books and original research papers of great value. He was the author or co-author of 24 books published by international editors such as Academic Press, and Oxford and Cambridge University Presses. He wrote more than 120 original scientific publications in leading histochemical and cytochemical journals such as Histochemie, Histochemistry, $C y$ tometry, Journal of Cell Science, Folia Histochemica et Cytobiologica as well as in Science (Science. 1985;230:1401-1403). His scientific organizational activity was manifested in his membership of editorial teams of scientific journals. He was a member of the editorial boards of many histo- and cytochemical journals: Histochemistry (1987-1993), Histochemical Journal (1987-1992), Cytometry (1979-1984), Cytogenetics and Cell Genetics (1992-1996), Folia Histochemica et Cytobiologica (1985-2011), 
Acta Histochimica et Cytochimica Japan, Applied Histochemistry and Cytochemistry (Basic and Applied Histochemistry), European Journal of Histochemistry, and Analytical Cytology Series (Academic Press). Mels van der Ploeg was a Member of the Executive Committee of the International Federation of Societies for Histochemistry and Cytochemistry: Treasurer (1984-1988), Honorary Secretary-General (1988-1992), and President (1992-1996).

Mels van der Ploeg was honored with distinctions, awards and honorary memberships from scientific institutions and societies. In 1986 he received Honorary Membership of the Polish Histochemical Society. The General Assembly of the Polish Academy of Arts and Sciences (PAU) at its Meeting on 19 June 1999 elected Mels van der Ploeg its Foreign Member of the Class of Natural Sciences. He was honored as well by 'Ornament' - 'token of appreciation for the Scientific Merit of your Research' - Center of $\mathrm{Hu}-$ man Heredity - 1991 - University of Leuven Belgium; he was the first awardee of the Maffo Vialli International Award for Histochemistry (1999 - Italy), and he was made an Honorary Member of the Italian Society for Histo- and Cytochemistry (2002).

Mels van der Ploeg first visited Poland in 1982, invited by the President of the Polish Histochemical and Cytochemical Society, Professor Aleksandra Stojałowska, to present his scientific achievements in Szczecin, Warsaw and Krakow. At that time, Poland was in "state of war", and it was a brave decision that, knowing that, Mels came to us, and was a witness to the Solidarity demonstrations. The next time Mels visited us, in May 1986, he was invited to discuss his non-radioactive method during a hybridocytochemical conference organized by A. Myśliwski in Gdansk, and he also visited the medical school in Poznan on that occasion. It is worth mentioning his lecture presented at that time in the Institute of Human Genetics of the Polish Academy of Sciences for members of the Genetic Committee of the Academy. This lecture was on how the non-radioactive in situ hybridization technique had contributed to progress in cell and molecular biology. Once again, Mels visited us in Poznan at the end of eighties to receive the diploma of Honor- ary Member of the Polish Histochemical and Cytochemical Society conferred on him earlier, in September 1986, on the occasion of the $25^{\text {th }}$ anniversary of the society. At that time, during the Christmas party at the histology department of Poznan medical school, he expressed his personal comment on a traditional custom in this country, i.e. breaking Christmas white wafer when the department members were exchanging holiday wishes to each other, that the atmosphere and his personal feelings at that time were solemn and unusual. Details of Mels's mRNA detection procedure by non-radioactive in situ hybridization in tissue sections and cultured cells were later discussed again by his co-workers during the hybridocytochemical symposium within the $9^{\text {th }}$ European Anatomical Congress held in Krakow in 1992. The problems of technical matters, specificity, sensitivity, and the possibility of detecting different mRNA sequences simultaneously in one cell were then discussed as compared to the results presented by L.-I. Larsson from Denmark, and researchers from this country. The experiences of Mels's research team were thereafter included in Immunocytochemia edited by M. Zabel (PWN, Warsaw, 1999).

Mels married Wiebrig Ubels (known as Wieke), his friend from his time at primary school, and they had four sons and many grandchildren. Mels and Wieke visited several regions of Poland, such as Kosarzyska near Piwniczna where they took part in boat fleet swimming over the Dunajec breaks. Mels loved nature and his specialty was the photography of flowers.

In putting together this biographical outline of the achievements and inquiring personality of Professor Mels van der Ploeg, we the undersigned express, on behalf of the Polish histochemical community, a profound memory and great indebtedness to him, primarily for his significant contribution to the development of histochemistry and cell and molecular biology in this and other countries. We would like to express our appreciation and gratitude for all his efforts that resulted in the improvement and strengthening of the organization of the Polish Histochemical and Cytochemical Society and his editing of the Society's quarterly Folia Histochemica et Cytobiologica. 